\title{
Penerapan Green Accounting Terhadap Profitabitas Perusahaan Di Indonesia
}

\author{
Tryas Chasbiandani, Nelyumna Rizal, dan Indra Satria
}

Fakultas Ekonomi dan Bisnis Universitas Pancasila Jakarta

Jl. Raya Lenteng Agung No. 56-80 Jakarta 12640, Indonesia

\section{Info Article}

Keywords:

Company profitability; Environmental performance; and Green accounting

ISSN (print) : 2598-7763 ISSN (online): 2598-7771

$\square$ Corresponding Author: Tryas Chasbiandani:

Tel. /Fax. +62 811-2707-913

E-mail: tryas@univpancasila.ac.id

\begin{abstract}
Abtract
The purpose of this study is to examine the effect of green accounting and environmental performance on company profitability. Green accounting and environmental performance as an accounting benchmark for corporate awareness and concern for an increasingly old earth. This study uses a sample of 58 manufacturing companies listed on the Indonesia stock exchange in 2017 and 2018 on the basis of an assessment of PROPER. Data were analyzed using panel data analysis with the help of eviews program. The results of this study indicate that green accounting and environmental performance have a positive effect on company profitability.
\end{abstract}

Citation: Chasbiandani, Tryas. Rizal, Nelyumna. Satria, Indra. (2019). Penerapan Green Accounting Terhadap Profitabilitas Perusahaan Di Indonesia. Accounting and Financial Review, 2 (2)

\begin{abstract}
Abstraks
Tujuan dari penelitian ini untuk menguji pengaruh green accounting dan kinerja lingkungan terhadap profitabilitas perusahaan. Green accounting dan kinerja lingkungan sebagai suatu tolak ukur akuntansi atas kesadaran dan kepedulian perusahaan terhadap bumi yang semakin tua. Penelitian ini menggunakan sampel 58 perusahaan manufaktur yang terdaftar di bursa efek Indonesia tahun 2017 dan 2018 dengan dasar penilaian dari PROPER. Data dianalisis menggunakan analisis data panel dengan bantuan program eviews. Hasil penelitian ini menunjukkan bahwa green accounting dan kinerja lingkugan berpengaruh positif terhadap profitabilitas perusahaan.
\end{abstract}

JEL Classification: M41, Q51

DOI: https://doi.org/10.26905/afr.v2i2.3722

\section{PENDAHULUAN}

Perkonomian modern seperti saat ini, telah memunculkan berbagai isu yang berkaitan dengan lingkungan seperti pemanasan global, ekoefisiensi, dan kegiatan industri lain yang memberi dampak langsung terhadap lingkungan sekitarnya (Agustia, 2010). Pada akuntansi konvensional perusahan hanya memberikan perhatian pada manjemen dan pemilik modal (stockholders dan bondholders), pihak yang lain sering terabaikan (Burhany, 2014). Tuntutan terhadap perusahaan semakin besar dan perusahaan harus melihat sisi baru yaitu tanggungjawab terhadap stakeholder, dimana perusahaan tidak hanya mementingkan kepentingan manajemen dan pemilik modal, tetapi juga karyawan, konsumen, serta masyarakat. Akuntansi memainkan peran yang sangat penting dalam mengelola hubungan antara perusahaan dengan lingkungan. Dari sudut pandang akuntansi, tanggung jawab sosial dan tanggung jawab lingkungan adalah tanggung jawab yang unik, terutama terkait dengan pengungkapan dan pelaporannya (Riduwan dan Andayani, 2011).

Dengan tujuan untuk peningkatan produktivitas dan efisiensi, berbagai usaha dilakukan o- 
leh perusahaan, di antaranya berproduksi menggunakan teknologi modern, pengurangan biaya, melakukan merger dan akuisisi, dan penggunaan sumber daya yang lebih murah. Upaya-upaya tersebut dilakukan untuk memberikan hasil maksimal bagi stakeholder. Namun, di era industri 4.0 justru perusahaan dituntut tidak hanya mengutamakan pemilik dan manajemen, tetapi juga seluruh pihak yang terkait, seperti karyawan, konsumen, serta masyarakat dan lingkungan. Hal ini karena keberadaan perusahaan tidak terlepas dari kepentingan berbagai pihak. Salah satunya adalah dukungan lingkungan. Seringkali usaha peningkatan produktivitas dan efisiensi mengakibatkan penurunan kualitas lingkungan, berupa pencemaran udara, air, dan pengurangan fungsi tanah. Pelestarian lingkungan di samping bermanfaat bagi masyarakat di sekitar juga bermanfaat bagi perusahaan secara jangka panjang (Kusumaningtias, 2013).

Penerapan akuntansi lingkungan yang dilakukan perusahaan, merupakan usaha dari perusahaan untuk memenuhi keinginan dari stakeholder, karena yang menjadi fokus dari stakeholder bukan hanya dari faktor keuangan perusahaan, tetapi juga terkait dengan faktor lingkungan perusahaan, apakah perusahaan tersebut memperhatikan dampak lingkungan dari kegiatan operasional perusahaan. Penerapan akuntansi lingkungan atau yang sering disebut green accounting yang baik oleh perusahaan, merupakan hal positif yang dimiliki perusahaan dimata stakeholder, karena dengan penerapan akuntansi lingkungan yang baik maka perusahaan tersebut telah memperhatikan dampak lingkungan perusahaan sekitar dan perusahaan dianggap tidak hanya fokus untuk meningkatkan laba perusahaan (Suka, 2016).

Pencapaian kinerja lingkungan yang baik bukanlah tujuan akhir perusahaan. Perusahaan berharap bahwa dengan kinerja lingkungan yang baik maka kinerja keuangan sebagai tujuan akhir juga dapat ditingkatkan, sebagaimana dikemukakan oleh De Beer dan Friend (2006) bahwa saat ini industri menjadi peduli dengan aspek lingkungan karena meyakini adanya pengaruh terhadap keuangan perusahaan. Semakin meningkatnya kesadaran manusia akan dampak kerusakan lingkungan yang akan mempengaruhi keberlangsungan hidup di masa yang akan datang, sehingga tuntutan masyarakat lebih besar. Karena pelestarian lingkungan di samping bermanfaat bagi masyarakat di sekitar juga bermanfaat bagi perusahaan secara jangka panjang. Dengan semakin berkembangnya ilmu pengetahuan, ilmu akuntansi berperan melalui pengungkapan sukarela dalam laporan keuangannya terkait dengan biaya lingkungan atau environmental costs. Mulai tahun 1970-an di Eropa mulai berkembang konsep Green Accounting (Gray \& Bebbington, 2001). Sistem akuntansi yang di dalamnya terdapat akun-akun terkait dengan biaya lingkungan ini disebut sebagai green accounting atau environmental accounting (Dewi, dkk. (2017). Dengan demikian green accounting adalah upaya meningkatkan perekonomian perusahaan tanpa mengabaikan keadaan lingkungan perusahaan.

Berdasarkan latar belakang di atas, penelitian ini dilakukan untuk menganalisis bagaimana penerapan green accounting terhadap profitabilitas perusahaan. Suatu bisnis mempunyai keprihatinan tentang masalah lingkungan ketika perusahaan memiliki keprihatinan tentang masalah lingkungan. Tujuan dari penelitian ini adalah menganalisis bagaimana dampak Green Accounting serta kinerja lingkungan atas profitabilitas (ROA) perusahaan manufaktur di BEI dan menganalisis bagaimana dampak Green Accounting serta kinerja lingkungan atas profitabilitas (ROE) perusahaan manufaktur di BEI.

\section{PENGEMBANGAN HIPOTESIS}

\section{Green Accounting (Akuntansi Lingkungan)}

Green accounting merupakan akuntansi yang di dalamnya mengidentifikasi, mengukur, menilai, dan mengungkapkan biaya-biaya terkait dengan aktivitas perusahaan yang berhubungan dengan lingkungan (Aniela, 2012). Green accounting adalah bagaimana memasukan konsukensi dari suatu peristiwa yang menyangkut lingkungan dalam laporan keuangan. Green accounting merupakan sarana untuk melaporkan suatu perusahaan yang dikaitkan dengan lingkungan. Tujuannya adalah memberikan informasi mengenai kinerja operasional perusahaan yang berbasis pada perlindungan lingkungan. Motivasi yang melatarbelakangi perusahaan untuk melaporkan permasalahan lingkungan lebih didominasi oleh faktor kesukarelaan (Ball, 2005). Akuntansi lingkungan memberikan laporan bagi pihak internal dan eksternal perushaan. Tujuan dari akuntansi lingkungan sebagai sebuah alat manajemen lingkungan dan sebagai alat komunikasi dengan masyarakat dan untuk meningkatkan jumlah informasi relevan yang dibuat bagi mereka yang memerlukan atau dapat menggunakannya, sehingga dapat mengetahui kegiatan perusahaan da- 
lam upaya menangani pencemaran lingkungan serta kewajiban perusahaan atas masalah tersebut melalui laporan keuangan perusahaan. Akuntansi lingkungan merupakan sarana untuk melaporkan operasional suatu perusahaan yang dikaitkan dengan biaya lingkungan (Carolina dan Martusa, 2009). Perusahaan yang ingin mencapai corporate sustainability di samping harus memperhatikan aspek ekonomi dan sosial, juga harus memperhatikan aspek lingkungan sehingga akan terjaga eksistensi perusahaannya dan sekaligus kelestarian lingkungannya (Sunaryo, 2013).

Peraturan-peraturan tentang Green Accounting: 1) Undang-Undang No. 23 Tahun 1997 tentang Pengelolaan Lingkungan Hidup. UU ini mengatur tentang kewajiban setiap orang yang berusaha atau berkegiatan untuk menjaga, mengelola, dan memberikan informasi yang benar dan akurat mengenai lingkungan hidup. Akibat hukum juga telah ditentukan bagi pelanggaran yang menyebabkan pencemaran dan perusakan lingkungan hidup. 2) Undang-Undang No. 25 tahun 2007 tentang Penanaman Modal. Dalam UU ini diatur kewajiban bagi setiap penanam modal berbentuk badan usaha atau perorangan untuk melaksanakan tanggungjawab sosial perusahaan, menjaga kelestarian lingkungan hidup dan menghormati tradisi budaya masyarakat sekitar. Pelanggaran terhadap kewajiban tersebut dapat dikenai sanksi berupa peringatan tertulis, pembatasan, pembekuan, dan pencabutan kegiatan dan atau fasilitas penanaman modal. 3) Undang-Undang No. 40 Tahun 2007 tentang Perseroan Terbatas. UU ini mewajibkan bagi perseroan yang terkait dengan sumber daya alam untuk memasukkan perhitungan tanggung jawab sosial dan lingkungan sebagai biaya yang dianggarkan secara patut dan wajar. Pelanggaran terhadap hal tersebut akan dikenakan sanksi sesuai dengan peraturan perundang-undangan yang berlaku. 4) Keputusan Ketua Badan Pengawas Pasar Modal dan Lembaga Keuangan No: KEP-134/BL/2006 tentang Kewajiban Penyampaian Laporan Tahunan bagi Emiten atau Perusahaan Publik. UU ini mengatur mengenai kewajiban laporan tahunan yang memuat Tata Kelola Perusahaan (Corporate Governance) harus menguraikan aktivitas dan biaya yang dikeluarkan berkaitan dengan tanggung jawab sosial perusahaan terhadap masyarakat dan lingkungan. 5) Pernyataan Standar Akuntansi Keuangan (PSAK) No. 32 (Akuntansi Kehutanan) dan No. 33 (Akuntansi Pertambangan Umum). Kedua PSAK ini mengatur tentang kewajiban perusahaan dari sektor pertambangan dan pemilik Hak Pengusaha Hutan (HPH) untuk melaporkan item-item lingkungannya dalam laporan keuangan.

PBI No. 7/2/PBI/2005 tentang Penetapan Peringkat Kualitas Aktiva Bagi Bank Umum. Dalam aturan ini aspek lingkungan menjadi salah satu syarat dalam pemberian kredit. Setiap perusahaan yang ingin mendapatkankredit perbankan, harus mampu memperlihatkan kepeduliannya terhadap pengelolaan lingkungan. Standar pengukur kualitas limbah perusahaan yang dipakai adalah PROPER. Dengan menggunakan lima peringkat (hitam, merah, biru, hijau, dan emas) perusaahaan akan diperingkat berdasarkan keberhasilan dalam pengelolaan limbahnya.

\section{Kinerja Lingkungan}

Kinerja lingkungan mengacu pada seberapa besar dampak dan kerusakan yang telah disebabkan oleh kegiatan bisnis perusahaan. Pembuangan limbah dan bagaimana cara pengelolaan limbah dari perusahaan sehingga mampu meminimalisir kerusakan lingkungan disekitaran pabrik dan pengelolaan produksi bisnis perusahaan. Kerusakan lingkungan yang semakin minim dianggap akan meningkatkan kinerja lingkungan dari suatu perusahaan, sedangkan semakin besar dampak kerusakan lingkungan, semakin buruk kinerja perusahaan.

PROPER sebagai suatu program pemeringkatan yang didapat digunakan untuk menilai kemampuan di dalam manajemen lingkungan, digunakan oleh peneliti untuk mengukur Kinerja Lingkungan perusahaan Indonesia.

\section{Kerangka Pemikiran}

Kerangka pemikiran yang dikembangkan dalam penelitian ini disajikan pada gambar 1 . Berdasarkan gambar 1 menunjukkan Green Accounting dan Kinerja Lingkungan berpengaruh terhadap Profitabilitas.

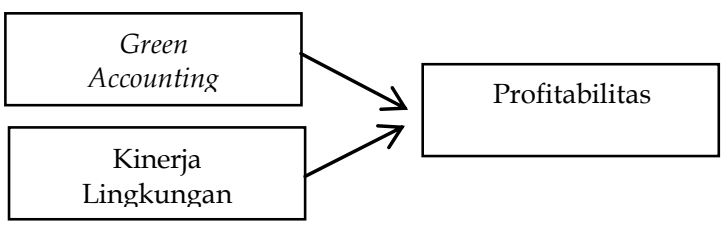

Gambar 1. Kerangka Pemikiran

\section{Akuntansi Lingkungan terhadap Profitabilitas}

Pelaksanaan akuntansi lingkungan yang baik akan memberikan dampak yang besar bagi investor dan konsumen perusahaan, kepercayaan dari konsumen akan meningkat terhadap perus- 
ahaan tersebut. Hal tersebut akan membuat citra dari perusahaan akan semakin meningkat, sehingga profitabilitas perusahaan juga akan meningkat.

$\mathrm{H}_{1}$ : Akuntansi Lingkungan berpengaruh terhadap Profitabilitas

\section{Kinerja Lingkungan terhadap Profitabilitas}

Besarnya penghargaan yang diberikan oleh pemerintah atas kinerja lingkungan yang telah dilakukan oleh perusahaan akan memberikan dampak terhadap besarnya persepsi investor jika perusahaan mendapat penghargaan yang besar dari aspek pengelolaan lingkungan, maka persepsi investor dan customer terhadap produk perusahaan tinggi dalam menjaga keseimbangan lingkungan menjadi tinggi. Hal ini sejalan dengan penelitian Sulistiawati dan Dirgantari (2016).

$\mathrm{H}_{2}$ : Kinerja Lingkungan berpengaruh terhadap profitabilitas

\section{DATA DAN METODE}

Tujuan dari model empiris adalah untuk menguji hipotesis-hipotesis penelitian yang telah dijelaskan dibagian sebelumnya. Dalam model empiris tersebut, dimana seluruh variabel independen yang diduga mempengaruhi variabel dependen dimasukkan secara bersama-sama untuk melihat pengaruh dari masing-masing variabel independen terhadap variabel dependen. Untuk menguji hipotesis, model yang digunakan :

$$
\text { Prof }=\alpha+\beta_{1} G A+\beta_{2} K L+e
$$

Keterangan: Prof $=$ profitabilitas perusahaan yang diukur dengan Return on Asset dan Return on Equity; $a=$ konstanta; $\beta_{1-2}=$ koefisien regresi; $\mathrm{GA}=$ green accounting; $\mathrm{KL}=$ kinerja lingkungan .

Variabel dalam penelitiqan ini terdiri dari variable dependent dan independent. dependen dalam penelitian ini adalah profitabilitas. Profitabilitas diukur dengan menggunakan ROA dan ROE. Sedangkan Variabel Independen, berupa green accounting dan kinerja lingkungan. Variabel green acconting dapat diukur dengan menggunakan metode dummy. Jika suatu perusahaan tersebut mempunyai salah satu komponen biaya lingkungan, biaya komponen lingkungan, biaya daur ulang produk, dan biaya pengembangan dan penelitian lingkungan dalam annual report maka akan diberi score 1 , tetapi jika tidak mempunyai komponen biaya lingkungan dalam laporan annual report score nilai 0 .
Variabel kinerja lingkungan dapat diukur oleh perusahaan yang berpartisipasi dalam PROPER atau Program Peringkat Kinerja Perusahaan dalam Pengelolaan Lingkungan Hidup, sebuah instrumen dari kementerian lingkungan hidup (Cahyani dan Bahri, 2016). Kinerja Lingkungan diukur dengan menggunakan tingkatan warna PROPER, dimana 1) Skor 5 untuk peringkat emas; 2) Skor 4 untuk peringkat hijau; 3) Skor 3 untuk peringkat biru; 4) Skor 2 untuk peringkat merah dan 5) Skor 1 untuk peringkat hitam

Populasi dalam penelitian ini yaitu perusahaan manufaktur yang sahamnya (listing) dan tercatatkan di Bursa Efek Indonesia periode 20172018 dan telah terdaftar di PROPER tahun 20172018. Teknik pengambilan sampel pada penelitian ini dilakukan dengan menggunakan teknik purposive sampling, yang berarti pemilihan sampel berdasarkan kriteria tertentu.

Pegolahan data dalam penelitian ini menggunakan Eviews 9.1. Hal ini dilakukan agar hasil yang diperoleh menghasilkan dugaan yang efisien. Diagram pengujian statistik untuk memilih model yang efisien dapat digambarkan dalam gambar 2.

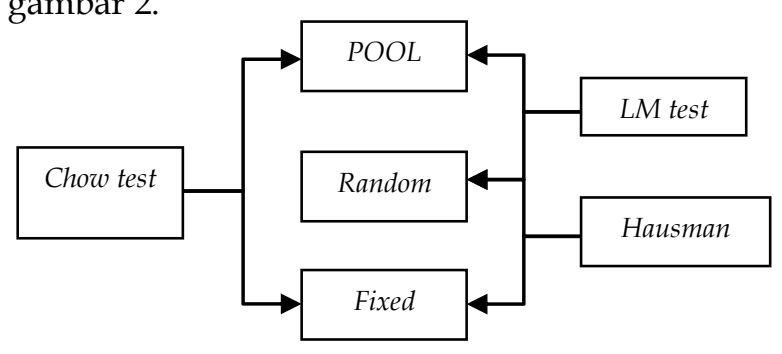

Sumber Baltagi (1995)

Gambar 2. Pemilihan Model Penelitian

Penelitian ini menggunakan panel data, yaitu gabungan dari data cross section dan data time series sehingga jumlah pengamatan menjadi sangat banyak, oleh karena itu diperlukan teknik tersendiri dalam mengatasi model yang digunakan dalam menggunakan data panel seperti yang dijelaskan sebelumnya.

Penelitian ini bertujuan untuk mengetahui pengaruh green accounting dan kinerja linkgugan terhadap profitabilitas perusahaan, dimana setiap perusahaan mempunyai karakteristik masing-masing dengan memperhatikan faktor dari individu maupun waktu sehingga tidak bisa dipandang sebagai keseluruhan (common effect). Dalam model penelitian ini juga tidak perlu mengasumsikan bahwa komponen error tidak berkorelasi dengan variabel bebas dimana hal ini sangat sulit untuk dipenuhi, sehingga pool effect meth- 
od dianggap lebih tepat daripada fixed effect meth$o d$. Dari hasil pengujian redundant fixed effect test nilai probabilitas $\mathrm{F}$ period lebih besar dari 0,05 , yang menunjukkan bahwa Ho tidak ditolak, model estimasi yang tepat untuk model ini adalah model common effect.

\section{HASIL}

Penelitian ini menggunakan variabel dependen profitabilitas perusahaan yang diukur dengan ROA dan ROE. Hasil analisis disajikan pada tabel 1.

Tabel 1. Hasil Analisis Regresi Dengan Profitabilitas Menggunakan ROA

\begin{tabular}{|c|c|c|c|}
\hline \multirow{2}{*}{ Nama Variabel } & \multicolumn{3}{|c|}{ Dependen Variabel : LRTA 10} \\
\hline & Prediksi & Koefisien & Prob \\
\hline $\mathrm{C}$ & (?) & 0,013350 & 0,3418 \\
\hline GA & + & 0,052970 & $0,000^{* * *}$ \\
\hline KL & + & 0,009591 & $0,0464^{* * *}$ \\
\hline Adjusted Rsquare & & & 664054 \\
\hline F-Stat & & & 14,6586 \\
\hline p-value & & & $000^{* * *}$ \\
\hline
\end{tabular}

ROA adalah Return on Asset.; GA adalah variabel green accounting perusahaan pada tahun 2018 dan tahun 2017. KL adalah variabel kinerja lingkungan perusahaan pada tahun 2018 dan tahun 2017. Dalam eviews, nilai $p$-value pada t-statistik merupakan pengujian untuk 2 arah, karena pengujian merupakan pengujian 1 arah, maka nilai $p$-value dari t-statistik dibagi $2 . .{ }^{* * *}$ untuk signifikan $1 \%$, ** untuk signifikan $5 \%$ dan * signifikan $10 \%$

Dari hasil pengujian regresi pada tabel 1 , nilai dari F-stat adalah sebesar 114,6586 dengan nilai $\mathrm{p}$-value sebesar 0,000 yang artinya model yang digunakan oleh penelitian ini sesuai, variabel Green Accounting serta Kinerja Lingkungan dapat berdampak signifikan simultan pada variabel dependen yaitu Profitabilitas (ROA). Nilai Adj $R_{\text {square }}$ sebesar 0,664054 yang berarti $66,40 \%$ variabel bebas dalam penelitian ini mampu menjelaskan variabel dependennya. Dari pengujian individu, green accounting berpengaruh positif terhadap profitabilitas perusahaan dengan tingkat signifikansi $1 \%$. Perusahaan menerapkan green accounting dalam laporan tahunannya, maka profitabilitas perusahaan semakin meningkat.

Hasil pengujian hipotesis untuk pengukur- an variabel profitabilitas menggunakan ROE disajikan pada tabel 2. Dari hasil pengujian regresi diatas, nilai dari F-stat adalah sebesar 26,25667 dengan nilai p-value sebesar 0,000 yang artinya model yang digunakan oleh penelitian ini sesuai, variabel Green Accounting serta Kinerja Lingkungan dapat berdampak signifikan simultan pada variabel dependen yaitu Profitabilitas (ROE). Nilai Adj $R_{\text {square }}$ sebesar 0,305192 yang berarti $30,52 \%$ variabel bebas dalam penelitian ini mampu menjelaskan variabel dependennya. Dari pengujian individu, green accounting berpengaruh positif terhadap profitabilitas perusahaan yang diukur menggunakan ROE dengan tingkat signifikansi $1 \%$.

Tabel 2. Hasil Analisis Regresi Dengan Profitabilitas Menggunakan ROE

\begin{tabular}{llcl}
\hline & \multirow{3}{*}{ Nama Variabel } & \multicolumn{3}{c}{ Dependen Variabel : LRTA 10 } \\
& Prediksi & Koefisien & Prob \\
\hline C & $(?)$ & 0,026018 & 0,2874 \\
GA & + & 0,049886 & $0,000^{* * *}$ \\
KL & + & 0,023704 & $0,0032^{* * *}$ \\
Adjusted Rsquare & & 0,305192 \\
F-Stat & & 26,25667 \\
p-value & & $0,000^{* * *}$ \\
\hline
\end{tabular}

ROE adalah Return on Equity.; GA adalah variabel green accounting perusahaan pada tahun 2018 dan tahun 2017. KL adalah variabel kinerja lingkungan perusahaan pada tahun 2018 dan tahun 2017. Dalam eviews, nilai $p$-value pada t-statistik merupakan pengujian untuk 2 arah, karena pengujian merupakan pengujian 1 arah, maka nilai $p$-value dari t-statistik dibagi $2 . .{ }^{* * *}$ untuk signifikan $1 \%$, ** untuk signifikan $5 \%$ dan * signifikan $10 \%$

\section{PEMBAHASAN}

Profitabilitas, baik yang diukur dengan $R e-$ turn on Asset (ROA) maupun yang diukur dengan
Return on Equity (ROE) memiliki pengaruh positif signifikan terhadap penerapan green accounting yang akan bernilai 1 jika suatu perusahaan mempunyai salah satu komponen biaya lingkungan, 
biaya komponen lingkungan, biaya daur ulang produk, dan biaya pengembangan dan penelitian lingkungan. Artinya, jika perusahaan menerapkan green accounting dalam laporan tahunannya, maka profitabilitas perusahaan semakin meningkat. Hal tersebut sejalan dengan penelitian yang dilakukan oleh Putri, Hidayati, dan Amin (2019); Sulistiawati dan Dirgantari (2016) dimana Green accounting memiliki dampak positif terhadap profitabilitas perusahaan.

Berdasarkan hasil pengujian regresi diatas menunjukkan bahwa kinerja lingkungan berpengaruh positif terhadap profitabilitas perusahaan (ROA dan ROE), yang berarti semakin baik nilai peringkat yang diberikan oleh PROPER, maka profitabilitas perusahaan semakin meningkat. Hal tersebut sejalan dengan penelitian yang dilakukan oleh Saadah dan Nurleli (2017); Sulistiawati dan Dirgantari (2016), Tang (2017), Andries dan Stephan (2019) dimana kinerja lingkungan memiliki dampak positif terhadap profitabilitas.

\section{SIMPULAN DAN SARAN}

Berdasarkan hasil diskusi yang telah dijelaskan sebelumnya, maka kesimpulan dalam penelitian ini Green Accounting berpengaruh positif pada Profitabilitas, baik profitabilitas tersebut diukur menggunakan ROE ataupun ROA. Selain itu, kinerja lingkungan juga berpengaruh positif terhadap Profitabilitas Perusahaan.

Variabel yang digunakan dalam penelitian ini terbatas pada green accounting dan lingkungan kinerja. Untuk penelitian selanjutnya dapat digunakan variabel yang lain, yang dapat mencerminkan kepedulian perusahaan terhadap lingkungan.

\section{DAFTAR PUSTAKA}

Aggarwal, P., (2013). Relationship between Environmental Responsibility and Financial Performance of Firm: A Literature Review. IOSR Journal of Business and Management (IOSR-JBM). 13 (1): 13-22.

Agustia, D., (2010). Pelaporan Biaya Lingkungan Sebagai Alat Bantu Bagi Pengambilan Keputusan yang Berkaitan Dengan Pengelolaan Lingkungan. Universitas Airlangga. 1 (2): 190-214.

Andries, P., and Stephan, U. (2019). Environmental Innovation and Firm Performance: How Firm Size and Motives Matter. Sustain- ability. 11: 1-17.

Aniela, Yoshi. (2012). Peran Akuntansi Lingkungan dalam Meningkatkan Kinerja Lingkungan dan Kinerja Keuangan Perusahaan. Berkala Ilmiah Mahasiswa Akuntansi. 1 (1)

Ball, A. (2005). Environmental accounting and change in UK local government. Accounting Auditing \& Accountability Journal 18 (3): 346373

Burhany, D.I., (2014). Pengaruh Implementasi Akuntansi Lingkungan Terhadap Kinerja Lingkungan Dan Pengungkapan Informasi Lingkungan (Studi pada Perusahaan Pertambangan Umum yang Mengikuti PROPER Periode 2008-2009) ). Politeknik Negeri Ujung Pandang.: 1-8.

Carolina, Verani dan Martusa, R. (2009). Akuntansi Lingkungan : Solusi untuk Problematika Penerapan Corporate Social Responsibility di Indonesia. Prosiding Seminar Nasional Problematika Hukum dalam Implementasi Bisnis dan Investasi.

De Beer, Patrick and Friend, Francois. (2011) Environmental Accounting: A Management Tool for Enhancing Corporate Environmental and Economic Performance. Ecological Economics. 58 (3): 548-560

Dewi, K., Nurleli, dan Lestari, R. (2017). Pengaruh Penerapan Akuntansi Manajemen Lingkungan terhadap Kinerja Lingkungan (Survey pada Perusahaan tekstil yang telah mengikuti PROPER di Kab. Bandung Tahun 2015-2016). Kajian Akuntansi. 18 (2): 97106

Gray, R \& Bebbington, J. (2001). Accounting for the Environment. SAGE Publications Ltd

Kusumaningtias, Rohmawat. (2013). Green Accounting, Mengapa dan Bagaimana? Proceeding Seminar Nasional dan Call for Paper Sancall.

Putri, Ayu Mayshella, Hidayati, Nur. dan Amin, M. (2019). Dampak Penerapan Green Accounting dan Kinerja Lingkungan Terhadap Profitabilitas Perusahaan Manufaktur Di Bursa Efek Indonesia. E-JRA 08 (4)

Riduwan, Akhmad dan Andayani. (2011). Dimensi Kritis Pemikiran Akuntansi Yang Teralienasi: Dialog Imajiner KOnstruksionis dan Dekonstruksionis. Jurnal Media Riset Akuntansi, Auditing \& Informasi. 19 (2): 167190

Saadah., I. A., dan Nurleli. (2017). Kinerja Lingkungan, Dan Tingkat Profitabilitas Serta 
Pengungkapan Informasi Lingkungan Sebagai Variabel Intervening". Proceeding Profesionalisme Akuntan Menuju Sustainable Business Practice SNAB; Universitas Widyatama Bandung: $404-415$.

Suka, E.A., (2016). Efektivitas akuntansi lingkungan dalam meningkatkan nilai perusahaan. Universitas Muhammadiyah Yogyakarta. 1-24.

Sulistiawati, E., dan Dirgantari, N. (2016). Analisis Pengaruh Penerapan green Accounting Terhadap Profitabilitas Pada Perusahaan pertambangan Yang Terdaftar Dibursa Efek Indonesia. Jurnal Reviw Akuntansian Keuangan, 6 (1): 865-872.

Sunaryo, A. S. (2013). Hubungan antara Persepsi tentang Kondisi Fisik Lingkungan Kerja dengan Sikap Kerja dalam Meningkatkan Etos Kerja Karyawan UD. ES WE di Surakarta. Talenta Psikologi. 2 (2): 106-116.

Syaiful Bahri, S. dan Cahyani, F.A., (2016). Pengaruh Kinerja Lingkungan Terhadap Corporate Financial Performance Dengan Corporate Social Responsibilty Disclosure Sebagai Variabel Intervening (Studi Empiris pada Perusahaan Manufaktur yang Terdaftar di BEI). Ekonika 1 (2)

Tang, M., Walsh, G., Lerner, D., Markus A. Fitza, A.M., and Li, Qiaohua. (2017). Green Innovation, Managerial Concern and Firm Performance: An Empirical Study. Business Strategy and the Environment. Bus. Strat. Env. 2017 